\title{
A SIMPLE INSTRUMENT FOR RECORDING DYE DILUTION CURVES FROM THE CIRCULATION
}

\author{
BY \\ ANTHONY D. JOSE AND GEORGE LATHAM \\ From The Hallstrom Institute of Cardiology, Royal Prince Alfred Hospital, Sydney \\ Received April 27, 1961
}

Dye dilution techniques can add greatly to the diagnostic information obtained by cardiac catheterization (Swan, 1959; Conn, 1959), and are used increasingly in any investigative work for measurement of the cardiac output.

The technical requirements for recording dye dilution curves from whole blood have been discussed elsewhere (Wood et al., 1960). The instruments generally available for this purpose use as the photo-sensitive element either an iron-selenium photo-emissive cell (Nicholson et al., 1957; Norman, 1959), or a photomultiplier tube (Milnor et al., 1953). The photo-emissive cell is inherently somewhat variable in response, and its current output is very small, requiring the associated use of either very sensitive galvanometers or expensive high-performance electronic amplifiers.

These disadvantages have been partly overcome by using a stronger light source and imbedding the photo-cell in resin (Norman, 1959), but at the expense of requiring special provision for heat dissipation, increasing the complexity of the instrument. The photomultiplier tube, although exellent in performance, needs an expensive high-voltage power supply.

The development of cadmium sulphide photoconductive cells* with excellent stability, and large current output for small changes in incident light, makes possible a considerably cheaper and more easily maintained instrument for recording dye dilution curves. The instrument described here was cheaply constructed in our own workshop, and has given faultless service over several months.

\section{CONSTRUCTION}

The photoconductive cell on which the instrument is based, the ORP-90 (Mullard Ltd.), is a vacuum-enclosed side-viewing cell, across the terminals of which can be applied a DC voltage up to 300 volts. The electric resistance of the cell falls with increasing incident light, at a sensitivity increasing linearly with the applied voltage. Spectral sensitivity is maximal at $670 \mathrm{~m} \mu$ wave-length and respectively 90,96 , and 34 per cent of maximum at 580, 620, and $800 \mathrm{~m} \mu$ wave-lengths.

The transducer is built in three parts-light housing, cuvette, and photocell housing. The light source is a 6 volt 3 watt car "festoon" bulb with linear filament, and is mounted in a small housing suitably vented to the air (Fig. 1). No lens system has been used. The cuvette is basically an "ebonite" plastic block ( 2 in. $\times 2$ in. $\times \frac{1}{4}$ in.) drilled to house polyethylene tubing (O.D. $2.0 \mathrm{~mm}$., I.D. $1.0 \mathrm{~mm}$.), and with a linear window cut to expose a length of tubing comparable to that of the light filament; the width of the window is two-thirds of the internal diameter of the tubing. A suitable gelatine light filter is interposed between the light housing and the cuvette (Wratten No. 29 for Evans Blue, No. 87 for indocyanine green). The photocell housing is a wooden block ( $1 \frac{1}{4}$ in. $\times 2$ in. $\times 3 \frac{1}{2}$ in.) drilled to house the cell (length $6 \mathrm{~cm}$., diameter $2 \mathrm{~cm}$.), and with a window cut to expose the light-sensitive area $(9 \times 26 \mathrm{~mm}$.). The three sections are carefully aligned, and bolted together taking care to avoid light leakage.

* Mullard Ltd., Torrington Place, London. 


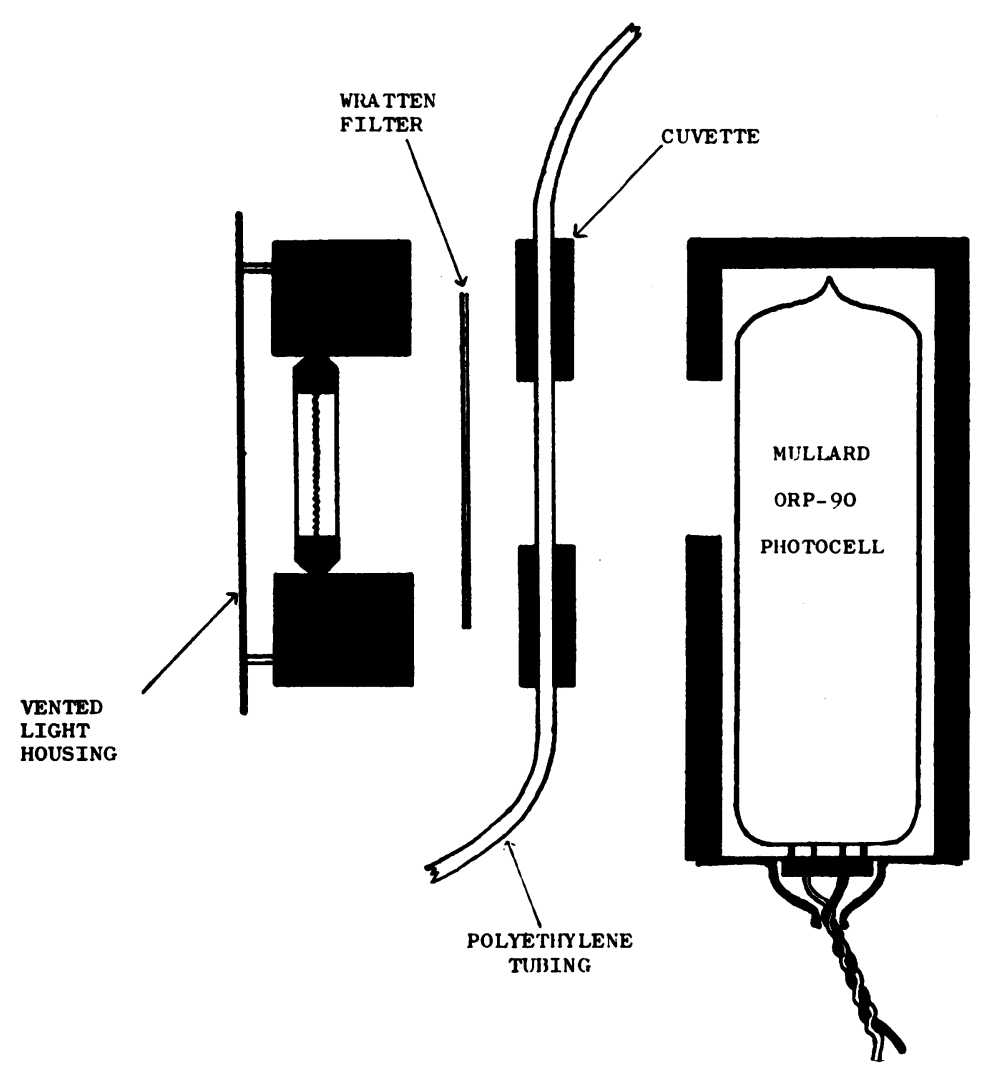

FIG. 1.-Section with parts separated to show method 'of construction of the transducer (see text). A thin protective leucite sheet has recently been inserted between light housing and gelatine filter.

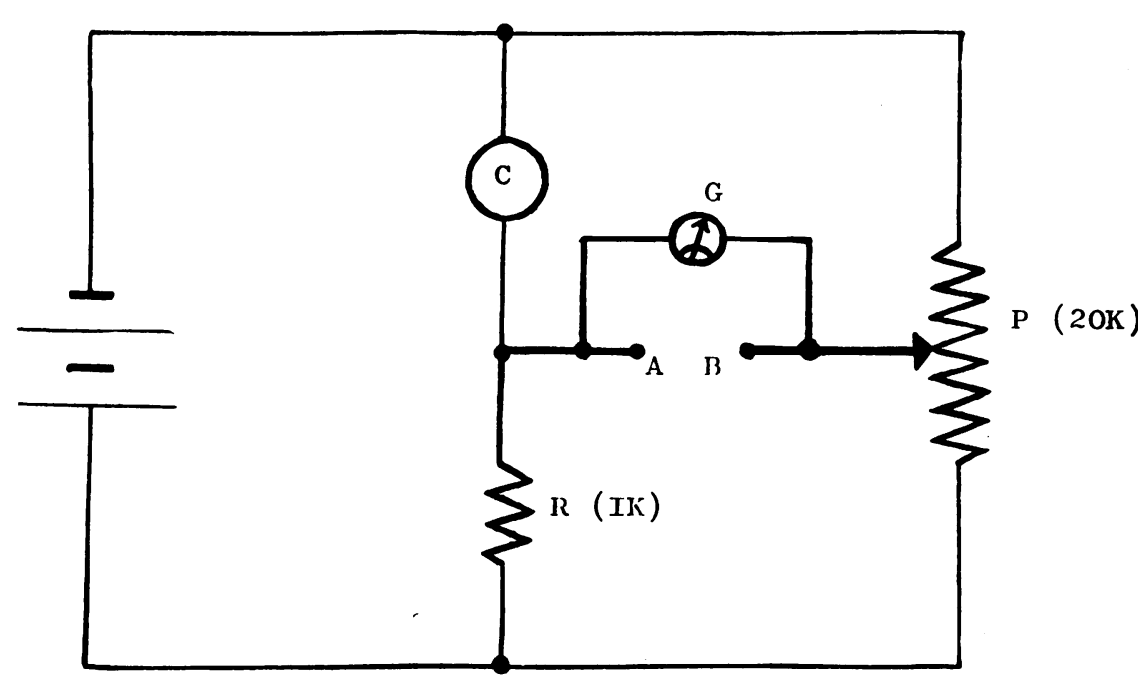

FIG. 2.-Circuit diagram. B-12 V storage battery; C-photoconductive cell; G-galvanometer, placed across output A-B. 

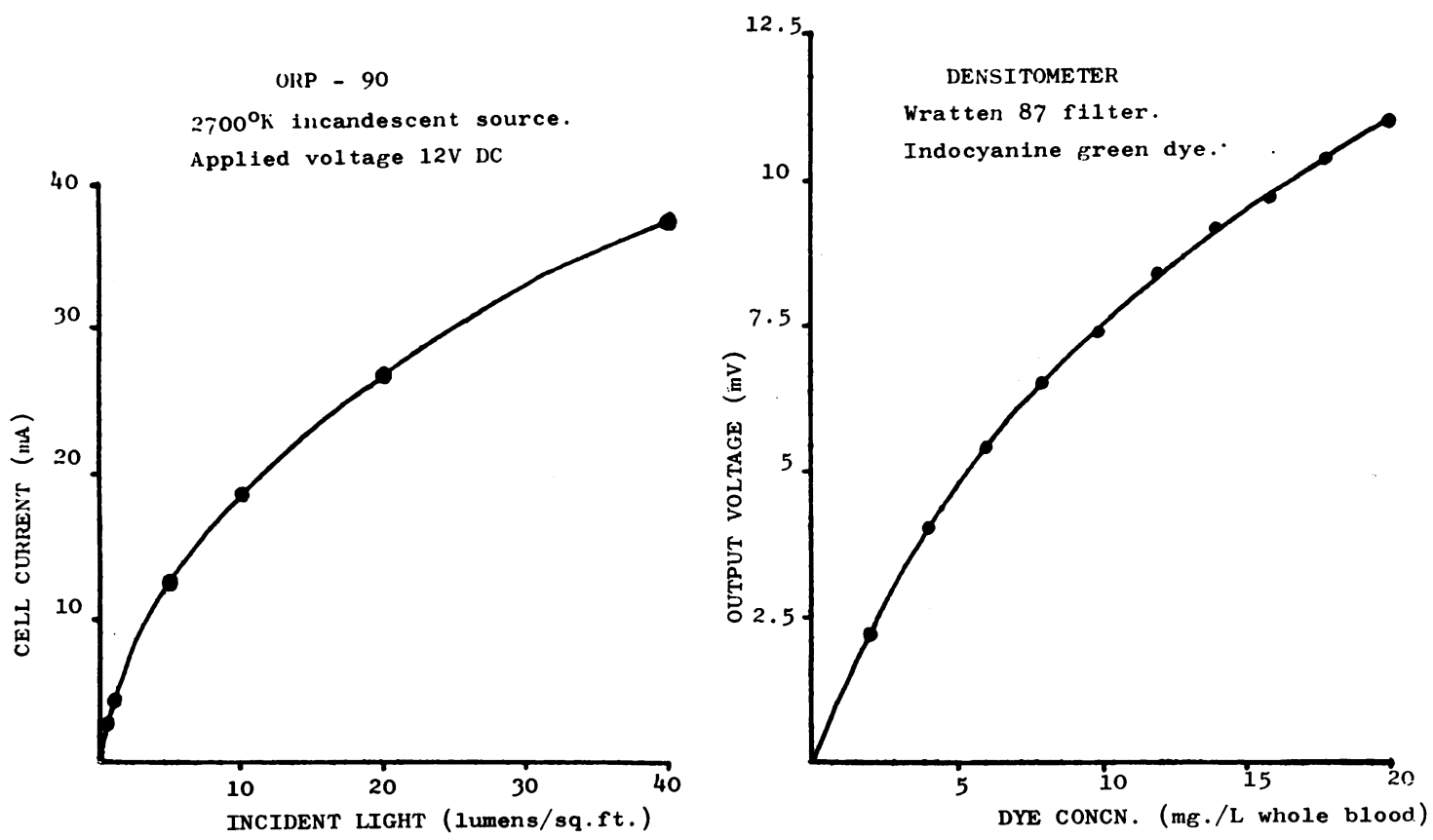

FIG. 3.-Left: The cell current related to the intensity of incident light when $12 \mathrm{~V} \mathrm{DC}$ is applied to the photocell. Right: Calibration curve of the instrument in operation, obtained in one patient (Note: only three calibration points are required in routine operation).

We have found that 12 volts DC applied to the cell gives adequate sensitivity, and use a 12 volt storage battery to provide this, with a 6 volt tap to supply the lamp. Under operating conditions, the cell resistance ranges between 500 and 1000 ohms. Changes in resistance are detected by incorporating the cell in a simple bridge circuit (Fig. 2). The potential difference across the output A-B is applied directly to the DC input of a standard recorder-amplifier, (electrocardiographic preamplifier, Model 1500, Sanborn Polyviso recorder). The circuit is housed in a small control unit close to the transducer. The bridge is balanced in operation by adjusting the potentiometer $(\mathrm{P})$ to give zero reading on the galvanometer (G). A switch is included on this unit to control both lamp and cell power supplies.

\section{Performance}

Before operation, the recorder pen is positioned at zero input voltage (i.e. with a balanced bridge). After blood has entered the cuvette, the bridge is rebalanced, automatically resetting the pen to the selected baseline. The voltage signal obtained is of the order of $0.5 \mathrm{mv}$. per mg./1. of Evans Blue in whole blood, and $0.7 \mathrm{mv}$. per $\mathrm{mg}$./1. of indocyanine green, using the appropriate light filters for each. This output is a curvilinear function of the dye concentration (Fig. 3). Three points, obtained in the usual way (Nicholson et al., 1957) are sufficient to establish this calibration curve in each patient. Inherently the cell is highly stable, and we have noted no change in its sensitivity over several months of regular operation. Small differences occur, as expected, in the calibration curves obtained for different patients.

The response time of the complete system was measured by introducing a "square-wave" of altered dye concentration into the cuvette as rapidly as possible; 90 per cent of full deflection was obtained in 0.44 seconds. From the rated characteristics of the cell, we have estimated that 0.35 seconds of this delay occurs in the cell, the remainder occurring in the hydraulic sampling system (Milnor and Jose, 1960). 
Changes in light transmission due to changes in the rate of blood flow through the cuvette are minimal with this design of blood chamber; satisfactory curves are obtained by manual withdrawal of blood into a large syringe, provided the flow is at least $0.2 \mathrm{ml}$. per second. If desired, the tubing and syringe can easily be sterilized, so that after each dilution curve, the blood withdrawn may be immediately reinfused.

\section{DisCUSSION}

For convenience, we have in this instrument used a weak light source and a low voltage applied to the photo-conductive cell. The sensitivity to change in blood concentration so obtained is more than adequate, and the response time tolerably fast for most purposes. Should improvement in performance be required for any special application, a brighter light source, the addition of a lens system to concentrate light, or the application of a higher voltage to the photocell will, through the inherent properties of the cell, increase sensitivity and shorten response time by large factors.

\section{SUMMARY}

The use of a photo-conductive cell for recording changes in dye concentration in whole blood makes possible a simple and cheap instrument for recording dye dilution curves from the circulation.

We are indebted to Messrs. W. J. Wheeler and R. H. Smith, of Mullard Ltd., Sydney, who supplied us with the photocells used, and with pertaining technical data.

\section{REFERENCES}

Conn, H. L. Jr. (1959). Progr. cardiovasc. Dis., 2, 166.

Milnor, W. R., Talbot, S. A., McKeever, W. P., Marye, R. B., and Newman, E. V. (1953). Circulation Res., $1,117$. - , and Jose, A. D. (1960). J. appl. Physiol., 15, 177.

Nicholson, J. W., Burchell, H. B., and Wood, E. H. (1957). J. Lab. clin. Med., 50, 598.

Norman, J. (1959). Brit. Heart J., 21, 107.

Swan, H. J. C. (1959). Progr. cardiovasc. Dis., 2, 143.

Wood, E. H., Sutterer, W. F., and Cronin, L. (1960). In Medical Physics. Year Book Publ. Inc., page 416. 